\title{
Regulation of the porcine corpus luteum during pregnancy
}

\author{
Adam J Ziecik¹, Emilia Przygrodzka', Beenu M Jalali² and Monika M Kaczmarek \\ ${ }^{1}$ Department of Hormonal Action Mechanisms, Institute of Animal Reproduction and Food Research PAS, Olsztyn, \\ Poland and ${ }^{2}$ Department of Immunology and Pathology of Reproduction, Institute of Animal Reproduction and \\ Food Research PAS, Olsztyn, Poland
}

Correspondence should be addressed to A J Ziecik; Email: a.ziecik@pan.olsztyn.pl

\begin{abstract}
The new corpora lutea (CLs) in pigs are formed from the preovulatory follicles after the luteinizing hormone (LH) surge. However, total autonomy and independence of CLs from LH up to Day 12 of cycle has recently been questioned. Transformation of estrous cycle $C L$ to $C L$ of pregnancy initiated by embryonic signals requires not only the cessation of prostaglandin $F 2\left(P F_{2 \alpha}\right)$ supply to the

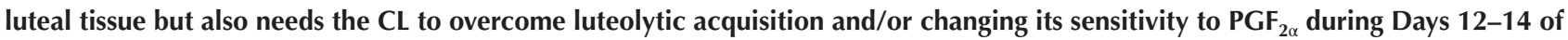
pregnancy. The luteolytic cascade is prevented by inhibition of lymphocyte infiltration and leucocyte recruitment, limitation of cell apoptosis, upregulation of pregnancy-associated genes and an enhanced antiluteolytic role of PGE ${ }_{2}$. Our 'two-signal switch hypothesis' highlights the importance of post $\mathrm{PGF}_{2 \alpha}$ and $\mathrm{PGE}_{2}$ receptor signaling pathways activation in CLs during luteolysis and rescue. The 'luteolytic switch' involves increased expression of many regression mediators and activation of the post PTGFR signaling pathway. The 'rescue switch' initiated by embryonic signals - estradiol $17 \beta$ and PGE $_{2}$ - induces post PTGER2/4 pathway, turning the 'luteolytic switch' off and triggering activity of genes responsible for CL maintenance. In mid and late pregnancy, CLs are maintained by LH and the synergistic action of metabolic hormones. This paper provides an outline of recent views on CL regression, rescue and maintenance during pregnancy in pigs that conflict with previous paradigms and highlights new findings regarding the actions of prostaglandins, role of microRNAs (miRNA) and immune system and signaling pathways governing the life cycle of porcine CL. Reproduction (2018) 156 R57-R67
\end{abstract}

\section{Introduction}

The life cycle of the corpus luteum $(\mathrm{CL})$ during the estrous cycle includes three phases: formation, maintenance and regression. However, the presence of embryo maintains the $\mathrm{CL}$ and instead of regression, $\mathrm{CL}$ undergoes rescue and the sustained maintenance during the 114 days long pregnancy in pigs. The presence of functional CLs is necessary not only for establishment but also for continuation of pregnancy until parturition. After Day 12 of each estrous cycle, when embryos are not present in the porcine uterus, CLs undergo regression that is crucial to prepare the ovaries for the next ovulation and to allow oocytes to be released and fertilized in the next cycle. This review is focused on the rescue and maintenance of porcine CLs during pregnancy, but some aspects of $\mathrm{CL}$ regression during the estrous cycle are also discussed.

The paradigmatic theories of maternal recognition of pregnancy, i.e. 'endocrine vs exocrine' (Bazer \& Thatcher 1977) and/or 'retrograde' (Krzymowski \& StefanczykKrzymowska 2004) transfer of prostaglandin $\mathrm{F}_{2 \alpha}\left(\mathrm{PGF}_{2 \alpha}\right)$ in the porcine reproductive tract were focused on the redirection of $\mathrm{PGF}_{2 \alpha}$ towards the ovary during the luteal phase or on $\mathrm{PGF}_{2 \alpha}$ accumulation in the uterus during early pregnancy respectively. Fortunately, the 'omics era' brought a handful of evidence for crucial roles of several other factors in $\mathrm{CL}$ rescue, thereby broadening our knowledge beyond a simple role of circulating PGF $_{2 \alpha}$ in CL regression (Østrup et al. 2010, Franczak et al. 2013, Zhang et al. 2013, Kiewisz et al. 2014). During pregnancy, $C L$ rescue is possible due to the paracrine action of conceptuses on both the endometrium and luteal tissue (for review see: Wacławik et al. 2017). For many years, estrogen was recognized as the most important secretion of embryonic origin involved in the maintenance of luteal function during pregnancy; however, our studies clearly indicated a strong role of conceptuses and uterine $\mathrm{PGE}_{2}$ in the rescue of porcine CLs (Waclawik \& Ziecik 2007, Przygrodzka et al. 2016). Here, we present our updated 'two signalswitch hypothesis' on the role of both $\mathrm{PGF}_{2 \alpha}$ and $\mathrm{PGE}_{2}$ signaling pathways in $\mathrm{CL}$ regression and rescue during the maternal recognition of pregnancy in the pig.

The lack of global profiling studies on pregnancyassociated genes involved in rescue of the porcine $\mathrm{CL}$ during pregnancy forced us recently to evaluate the expression of over 50 genes potentially involved in the process of porcine CL maintenance (Przygrodzka et al. 2015, 2016). Moreover, due to increasing understanding of the regulatory role of non-coding RNAs and, on the other hand, the lack of evidence for their involvement 
in luteal function maintenance, we decided to identify miRNAs in porcine CLs to target genes associated with luteal function maintenance (unpublished). The suggested roles of the most important genes and miRNA-mRNA interactions are discussed in this review and contrasted with the available scientific literature.

Finally, a role of potential pituitary stimuli (LH and prolactin) affecting luteal function during the estrous cycle and pregnancy is summarized and known controversies are discussed in the light of new evidence.

\section{$C L$ function during the estrous cycle}

\section{Formation, early maintenance and role of $\mathbf{L H}$}

During the last stages of follicular maturation under the influence of $\mathrm{LH}$, the theca and granulosa cells of the ovulatory follicle undergo luteinization and differentiation into luteal cells. After luteinization and formation of new CLs, both the granulosa- and theca-derived cells can utilize cholesterol for de novo steroidogenesis and production of progesterone, the major functional steroid and product of CLs (LaVoie 2017). The high production of progesterone in pigs is necessary to prepare the uterus for implantation and early conceptus development. The presence of CLs in pigs is required during the entire pregnancy.

The early reports of Du Mesnil Buisson and Leglise (1963) and Anderson et al. (1967) suggested that after the initial preovulatory $\mathrm{LH}$ surge, the porcine $\mathrm{CL}$ can act autonomously up to Day 12 of the estrous cycle, so neither hypophysectomy nor decreased LH levels by progesterone administration (Woody et al. 1967) cause immediate regression of this endocrine gland.

The application of specific anti-LH antibodies produced in pigs (Szafranska \& Ziecik 1989) significantly decreased progesterone concentrations in both nonpregnant gilts on Days 8-14 of the estrous cycle and pregnant animals on Days 42-46. Also, inhibition of $\mathrm{LH}$ secretion with a gonadoliberin $(\mathrm{GnRH})$ antagonist during the early luteal phase reduced $\mathrm{CL}$ development and progesterone production (Brussow et al. 2001), indicating that the porcine $\mathrm{CL}$ appears to be not as autonomous during the estrous cycle as was believed earlier (Bazer et al. 1982). This was further supported by in vitro studies showing $\mathrm{LH}$-induced secretion of progesterone by cultured large and small luteal cells (Buhr 1987) as well as slices of CLs collected at the midluteal phase (Przygrodzka et al. 2014).

The amplitude of LH pulses in the mid-luteal phase of the estrous cycle and early gestation reaches 50\% of the magnitude of the preovulatory LH surge (Ziecik et al. 1983), while their duration is $60-70 \mathrm{~min}$ with frequencies of 4-10 during $12 \mathrm{~h}$ (Hoover \& Young 1979). Although $\mathrm{LH}$ is thought to be main luteotropic hormone in pigs, there is no correlation between pulses of $\mathrm{LH}$ and progesterone in their blood plasma (Brinkley 1981,
Van de Wiel et al. 1981), except during late pregnancy (Parvizi et al. 1976).

Measurements of the luteal LH receptor (LHCGR) content in porcine CLs revealed dramatic changes during the cycle and early pregnancy. During the estrous cycle, its concentration peaks on Days 10 and 12 before declining as the CLs regress (Ziecik et al. 1980). Interestingly, administration of estrogen upregulates luteal LHCGR concentrations in non-pregnant animals (Garverick et al. 1982).

\section{Factors responsible for luteal regression during the luteal phase}

In the absence of embryonic signal(s) at the end of the luteal cycle, regression process in the pig is initiated; $\mathrm{CL}$ regression is mediated by pulsatile endometrial secretions of $\mathrm{PGF}_{2 \alpha}$ on Days 12-13 and 15-16 of the estrous cycle (Moeljono et al. 1977). The biological rationale for $\mathrm{CL}$ regression is preparation of the ovary for the next ovulation and to allow oocytes to be released and fertilized in the next cycle. The actions of $\mathrm{PGF}_{2 \alpha}$ include the reduction of steroidogenic enzyme activity and progesterone production within luteal tissue (Niswender 2000). In a number of studies, oxytocin (Carnahan et al. 1996), tumor necrosis factor $\alpha$ (TNF $\alpha$; Wuttke et al. 1998) and LH (Blitek \& Ziecik 2005) were suggested as potential modulators of endometrial prostaglandin production within luteal tissue.

The role of LH in luteolysis was, however, reported to be limited to the late luteal phase of the estrous cycle (Ziecik et al. 2001). Interestingly, both components of the porcine uterus, endometrium and myometrium, also possess LHCGR (Ziecik et al. 1986). The appearance of relatively high amounts of LHCGR in the endometrium coincides with the elevation of $\mathrm{PGF}_{2 \alpha}$ secretion (Moeljono et al. 1977) and perhaps with decreased expression of progesterone receptors (PGRs). After the beginning of luteolytic PGF $_{2 \alpha}$ release on Days 14-16, the amount of endometrial LHCGR declines. It was found that LH upregulates prostaglandin-endoperoxide synthase 2 (PTGS2) protein expression and PGF $_{2 \alpha}$ secretion from endometrial cells in vitro (Stepien et al. 1999). Furthermore, intravenous administration (Ziecik et al. 2001) or intramuscular challenge with human chorionic gonadotropin (hCG; Guthrie \& Bolt 1983) induces uterine $\mathrm{PGF}_{2 \alpha}$ release in vivo. It seems that a window of endometrial sensitivity to $\mathrm{LH}$ in vivo decreases during Days 15-17 of the estrous cycle. Additionally, there is a much higher correlation between peaks of $\mathrm{LH}$ and PGF $_{2 \alpha}$ metabolite (PGFM; 75.5\%; Ziecik et al. 2001) than between oxytocin and PGFM (30\%; Kotwica et al. 1999). This means that the majority of the 'luteolytic' action of $\mathrm{LH}$ via its endometrial receptors contributes to destruction of unnecessary cyclic CLs to allow the next ovulation and another chance for successful conception. The luteal regression occurring on Days 13-14 of the 
estrous cycle is also thought to be caused by an increase of luteolytic sensitivity (LS) by CLs to endometrial PGF $2 \alpha$.

The mechanisms responsible for luteal regression are complex and still not well understood in pigs. There are older and some recent reviews summarizing the roles of several molecules involved in luteolysis (Ziecik 2002, Wacławik et al. 2017, Ziecik et al. 2017). Many of the identified factors associated with luteal regression, such as endothelin 1 (EDN1), hypoxia-inducible factor $1 \alpha$ (HIF1A), estrogen receptor 2 (ESR2) and PTGS2, undergo profound changes in their expression levels after Day 12 of the estrous cycle when CLs have acquired LS. Simultaneously, decreased expression of genes involved in lipid cleavage was observed (Przygrodzka et al. 2016; Fig. 1).

Data on the role of inflammatory cytokines and immune cells in the control of luteolysis are also limited in pigs. Our recent results, however, have revealed that genes associated with infiltration of lymphocytes are induced during the beginning of functional regression in the pig (Przygrodzka et al. 2016). The role of macrophages in luteal regression is well established in
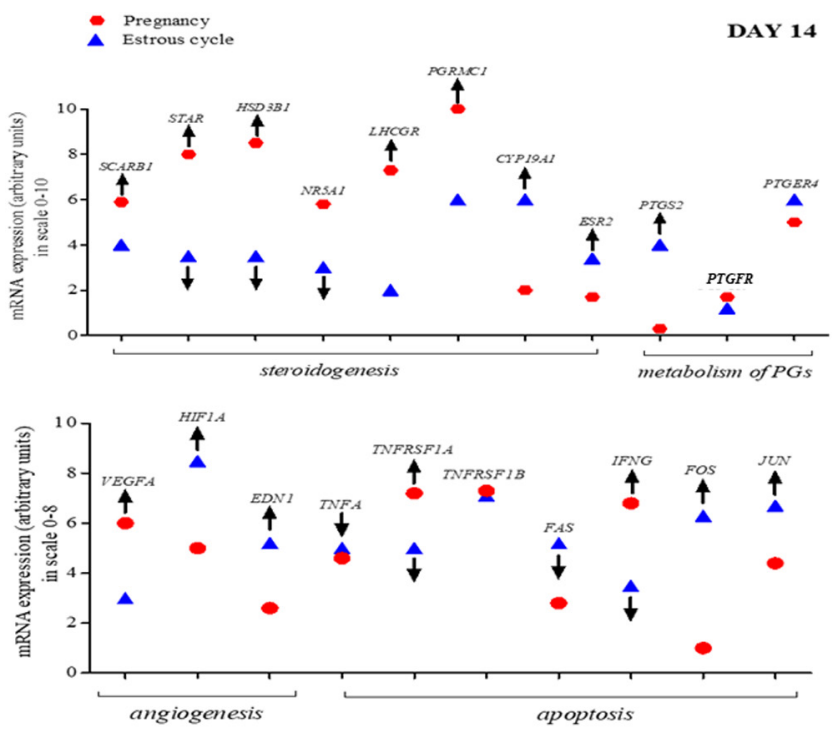

Figure 1 Schematic presentation of mRNA expression of 21 genes potentially involved in the function of porcine CL on Day 14 of the estrous cycle and pregnancy. Arrows indicate decrease $(\downarrow)$ or increase $(\uparrow)$ of transcript when compared to Day 12 of the estrous cycle/ pregnancy. CYP19A1, cytochrome P450 family 19 subfamily A member 1; ESR2, estrogen receptor 2; HSD3B1, 3 beta hydroxysteroid delta-isomerase 1 ; LHCGR, lutropinchoriogonadotropic hormone receptor; NR5A1, nuclear receptor subfamily 5 , group $\mathrm{A}$, member 1 ; $P G R M C 1$, progesterone receptor membrane components 1 ; PTGS2, prostaglandin-endoperoxide synthase 2; PTGER4, prostaglandin $\mathrm{E}_{2}$ receptor 4; PTGFR, prostaglandin F receptor; EDN1, endothelin 1; HIF1A, hypoxiainducible factor $1 \alpha$; IFNG, interferon gamma; SCARB1, scavenger receptor class $B$, member 1 ; STAR, steroidogenic acute regulatory protein; 1 TNFA, tumor necrosis factor alpha; TNFRSF1A and TNFRSF1B, tumor necrosis factor receptor superfamily member $1 \mathrm{~A}$ and $1 \mathrm{~B}$; VEGFA, vascular endothelial growth factor $\mathrm{A}$. pigs (Zhao et al. 1998, Chang et al. 2017). Macrophages are present in all phases of the porcine CL lifespan and their function depends on the luteal microenvironment and phase of the estrous cycle. However, their numbers are highest during the late luteal phase. Macrophages are the primary source of $\mathrm{TNF} \alpha$, an inflammatory cytokine involved in the regression process during the late luteal phase (Zhao et al. 1998). The LS to $\mathrm{PGF}_{2 \alpha}$ is also known to be associated with infiltration of macrophages into the porcine CL (Chang et al. 2017). Using flow cytometry, we showed that, whereas $T \gamma \delta$ (T-null) cells might have a role in $\mathrm{CL}$ regression, Treg (regulatory $\mathrm{T}$ cells) percentages were higher in CLs obtained from pregnant animals on Days 13-14. Although only a small proportion of T cells were $T \gamma \delta$, their percentage was significantly higher on Day 14 of the estrous cycle compared to Day 9 (Andronowska A, Jalali BM, Likszo P \& Witek K unpublished data). Leukocyte-derived cytokines such as TNF $\alpha$, interferon $\gamma$ (IFN $\gamma$ ) and interleukins (IL-1, IL-4 and IL-6) are present in the $\mathrm{CL}$ at different stages of the luteal phase (Sakumoto et al. 2006, Zmijewska et al. 2012). Both TNF $\alpha$ and IFN $\gamma$ are known to interact with $\mathrm{PGF}_{2 \alpha^{\prime}}$ leading to a decline in progesterone synthesis (Sakumoto \& Okuda 2004). TNF $\alpha$ is also involved in structural luteolysis through its role in apoptosis (Okano et al. 2006). Sensitization of porcine CLs to the luteolytic action of $\mathrm{PGF}_{2 \alpha}$ involves upregulation of TNF $\alpha$ observed on Days 12-14 of the estrous cycle (Przygrodzka et al. 2014). The action of TNF $\alpha$ is mediated through two different receptors (TNFR1 and TNFR2) in porcine luteal and endothelial cells. TNFR1 mediates an apoptotic function because it possesses a death domain. On the other hand, TNFR2 is rather involved in the anti-apoptotic effects of TNF $\alpha$. Indeed, a contribution of the TNF $\alpha$ pathway to survival, development and differentiation of porcine CLs during early gestation has been shown by Przygrodzka et al. (2015). In pigs, an increased presence of both TNFR1 mRNA and protein was found on Day 12 of the estrous cycle, but whether the luteolytic action of TNF $\alpha$ is dependent on the level of TNF $\alpha$ or the abundance of TNFR1 as proposed for bovine CLs (Skarzynski et al. 2003) needs further investigation.

Structural luteolysis in the porcine $\mathrm{CL}$ has been reported to be associated with apoptosis (Zorrilla et al. 2013, Przygrodzka et al. 2015). However, no change has been observed in the expression of apoptotic markers such as BAX and BCL2 or in BAX/BCL2 ratio during luteal regression (Przygrodzka et al. 2015). Similarly, the expression of caspase 3 and caspase 8 is also maintained at steady levels during the mid and late luteal phases of the estrous cycle (Zorrilla et al. 2013). However, mRNA expression of factors associated with extrinsic apoptosis (TNFA, TNFRSF1A, FAS and IFNG) are already elevated on Day 12 of the estrous cycle compared to the same day of pregnancy, while TNRSF1A showed higher abundance in luteal 
tissue of pregnant gilts on Day 14 (Fig. 1). Two factors involved in apoptotic pathways (FOS, JUN) showed distinct upregulation on Day 14 of the estrous cycle compared to earlier days (Przygrodzka et al. 2015; Fig. 1). Our proteomic data showed higher abundance of N-ethylmaleimide-sensitive factor (NSFL1) and heat shock protein b6 (HSPb6) and a decrease in eukaryotic elongation factor 1 (eEF1) and lysosomal adaptor MTOR activator (LAMTOR3) on Day 16 of the estrous cycle relative to the corresponding day of gestation. Since NSFL1, HSPb6 and LAMTOR3 are involved in autophagy and eEF1 is a known modulator of apoptotic proteins, there is a possibility that luteolysis in pigs is associated with autophagy and apoptosis (Jalali BM, Likszo P \& Skarzynski DJ 2017 unpublished observations).

Unlike in other species such as humans and cattle, the level of vascular endothelial growth factor $A$ (VEGFA) mRNA is maintained almost constant until Day 15 of the estrous cycle in pigs (Kaczmarek et al. 2007, Przygrodzka et al. 2016). There is a decrease in the expression of VEGFA and its receptors only during the late estrous cycle (Days 16-17; Kaczmarek et al. 2007). Luteal expression of VEGFA during pregnancy (Days 16-25) is similar to Days 5-12 of the estrous cycle. Other angiogenic factors such as angiopoietins (ANGPT1, ANGPT2) do not seem to be associated with luteal regression in pigs (Przygrodzka et al. 2016).

\section{Rescue and maintenance of CLs for pregnancy Old theories and new aspects of maternal recognition of pregnancy}

The luteolytic effect of $\mathrm{PGF}_{2 \alpha}$ on structural and functional luteolysis needs to be prevented during early pregnancy in order to rescue the CLs, since the maintenance of luteal function ensures continued release of progesterone needed for the secretion of specific endometrial products and constituents of the histotroph required for blastocyst growth and development. It is believed that at least $4 \mathrm{ng} /$ $\mathrm{mL}$ progesterone in the circulation is critical to maintain pregnancy in the pig (Ellicott \& Dziuk 1973) and removal of CLs during pregnancy results in its termination (Belt et al. 1971).

According to the original theory of maternal recognition of pregnancy in pigs created by Bazer and Thatcher (1977), the main role in the process of $\mathrm{CL}$ rescue is played by conceptus-driven redirection of endometrial $\mathrm{PGF}_{2 \alpha}$ secretion after Day 12 post coitum (p.c.) from endocrine to exocrine, i.e., into the uterine lumen. Thus, the threshold level of $\mathrm{PGF}_{2 \alpha}$ concentration in the peripheral blood reaching the luteal tissues is too low to begin luteolysis. An alternative antiluteolytic mechanism was proposed by Krzymowski and Stefanczyk-Krzymowska (2004), based on the retrograde transfer of $\mathrm{PGF}_{2 \alpha}$ from the uterine venous blood and lymph into the uterus, causing $\mathrm{PGF}_{2 \alpha}$ accumulation in the veins and arterial walls of the uterus instead of reaching the late luteal CLs.

A closer look into $\mathrm{CL}$ characteristics helped us to understand that the prolonged insensitivity to the luteolytic action of $\mathrm{PGF}_{2 \alpha}$ during early pregnancy was also explained by decreased numbers of $\mathrm{PGF}_{2 \alpha}$-binding sites in freshly isolated luteal cells obtained from porcine CL on Day 14 of pregnancy in comparison to Day 14 of the estrous cycle (Gadsby et al. 1990, 1993). However, more recent ex situ studies performed on whole porcine luteal tissue even showed an increase of PTGFR protein and mRNA in CL on Days 12 and 14 of pregnancy relative to the same days of the estrous cycle (Przygrodzka et al. 2016). A similar abundance of PTGFR mRNA was reported in cycling and early pregnant sheep (Wiepz et al. 1992). Davis and Rueda (2002) also suggested the presence of alternatively spliced PTCFR in ovine CLs, leading to either their reinforcement or destruction.

This discrepancy between the earlier pioneering work of Gadsby et al. $(1990,1993)$ and our recent results (Przygrodzka et al. 2014, 2016) could be due to at least two reasons: application of completely different methods, i.e., receptor binding sites vs Western blot and/or PCR, and use of isolated luteal cells instead of whole luteal tissue. Worth mentioning is the presence of PTGFR not only on luteal but also on endothelial cells (Zannoni et al. 2007) responsible for building vascular network of the CL. Interestingly, Przygrodzka et al. (2016) found an elevated intraluteal content of PGF $_{2 \alpha}$ on Day 14 of the estrous cycle vs the corresponding day of gestation, confirming earlier suggestions of possible $\mathrm{PGF}_{2 \alpha}$ production in CLs with acquired LS (Diaz et al. 2000, Wasielak et al. 2008). It seems that protein expression of PTGFR is decreased in CLs on Day 14 of the estrous cycle due to a negative correlation between high levels of luteal PGF $2 \alpha$ and PTGFR abundance (Diaz et al. 2000). In contrast to reports by Gadsby et al. (1990, 1993), the above-mentioned recent observations and earlier report by Zorrilla et al. (2009) suggest that induction of different post PTGFR signaling networks including specific kinase C (PKC) expression is more important than PTGFR abundance during the course of luteolysis.

Besides the well-known and described role of conceptus estrogens in the rescue of porcine CLs from luteolysis during establishment of pregnancy (Ford et al. 1982), $\mathrm{PGE}_{2}$ started to be recognized as another or second conceptus signal in the pig (Wacławik et al. 2017). The antiluteolytic role of $\mathrm{PGE}_{2}$ in the pig was known for decades, ever since an increased ratio of $\mathrm{PGE}_{2} / \mathrm{PGF}_{2 \alpha}$ content in the uterus was observed during the period of maternal recognition of pregnancy (Christenson et al. 1994). The expression of microsomal $\mathrm{PGE}_{2}$ synthase-1 (mPGES-1) is observed in spherical conceptuses since Day 10 p.c. and dramatically increases in tubular conceptuses on Day 13 
(Waclawik \& Ziecik 2007). The production of $\mathrm{PGE}_{2}$ in embryos and the endometrium seems to be involved in the escape of porcine CLs from luteolysis due to (1) a much higher luteal concentration of $\mathrm{PGE}_{2}$ on Day 14 of pregnancy than on the same day of the estrous cycle (Przygrodzka et al. 2016) and (2) higher PGE $_{2}$ content only in CLs ipsilateral to the gravid horn of unilaterally pregnant gilts (Wasielak et al. 2008), not accompanied by increased mPGES-1 expression. In addition, a local transfer of $\mathrm{PGE}_{2}$ via blood and lymph vessels from the uterus to the ovary (Stefanczyk-Krzymowska et al. 2006) can aid this process. The porcine $C L$ possesses at least two forms of $\mathrm{PGE}_{2}$ receptors: $\mathrm{PGE}_{2}$ receptor 2 (PTGER2) and $\mathrm{PGE}_{2}$ receptor 4 (PTGER4), both upregulated on Day 14 of pregnancy and participating in the production of progesterone in cultured luteal slices through a cAMP-mediated pathway (Waclawik et al. 2010). Our recent study revealed an increased phosphorylation of protein kinase A (PKA) at the position of Threonine 197 (Thr197), cAMP response element-binding protein (CREB) at the position of Serine 133 (Ser133) and protein kinase B (PKB) at the position of Serine 473 (Ser473) in porcine $\mathrm{CL}$ on Day 14 of pregnancy compared to the same day of the estrous cycle. Simultaneously, we observed an increase in levels of $\mathrm{PGE}_{2}$ and elevated content of steroidogenic acute regulatory protein (STAR), aromatase CYP19A1 (cytochrome P450 family 19 subfamily A member 1) and VEGFA in luteal tissue slices on Day 14 of pregnancy (E Przygrodzka, A Waclawik \& A J Ziecik, unpublished observations). These results suggest that binding of $\mathrm{PGE}_{2}$ to PTGER2/4 may activate PKA and PKB signaling pathways as well as enhance the expression of proteins involved in processes determining maintenance of luteal function during early pregnancy in pigs. Moreover, $\mathrm{PGE}_{2}$ significantly stimulated VEGFA secretion by luteal cells on Days 10-12 of gestation (Kowalczyk et al. 2008). Additionally, downregulation of endogenous antagonist of VEGFA-soluble receptor (sFLT1) in porcine CLs during early pregnancy may serve to enhance their content of bioavailable VEGFA. Consequently, prolonged progesterone secretion appears to be possible due to increased permeability of luteal small blood vessels and supply of cholesterol to the cells as well as easier transfer of prostaglandins from the peripheral circulation (Kaczmarek et al. 2009).

The evidence that $\mathrm{PGF}_{2 \alpha}$ may stimulate progesterone secretion in early CLs of the estrous cycle and during early gestation or inhibit it in CLs approaching luteolysis was documented in early in vivo experiments employing a microdialysis system (Wuttke et al. 1998). Also the 'luteolytic' $\mathrm{PGF}_{2 \alpha}$ elevated production of $\mathrm{CAMP}$ previously stimulated via both increased $\mathrm{Ca}^{2+}$ release and PKC activation in bovine CLs (Mamluk et al. 1999). Recently, it was shown that $\mathrm{PGF}_{2 \alpha}$ increased the content of CREB in CL slices of early pregnant pigs and progesterone secretion in mid-luteal phase CLs, but decreased progesterone production by luteal slices from CLs with acquired LS at the late-luteal phase (Przygrodzka et al. 2014, 2016).

The aforementioned studies show the dual and opposing roles of $\mathrm{PGF}_{2 \alpha}$ in the porcine $\mathrm{CL}$, depending on the phase of the estrous cycle and pregnancy, i.e., its luteotropic role in CLs without acquired LS (early CLs during the estrous cycle and CLs of early pregnancy) and its luteolytic role in CLs with acquired LS (the late luteal phase of the estrous cycle, approaching luteolysis).

\section{Lessons learned from gene expression studies}

Unfortunately, so far, there is a lack of global profiling studies on pregnancy-associated genes contributing to the antiluteolytic mechanisms in the porcine CL. Such data are available for ovine CLs (Romero et al. 2013) and revealed 734 genes differentially expressed on Day 14 of pregnancy. On the other hand, early stages of luteolysis (Days 12-14) in the sheep were associated with altered expression of 682 genes in the luteal tissue. However, different embryo signaling systems for $\mathrm{CL}$ rescue in ruminants (IFNT) and pigs (mainly $\mathrm{E}_{2}$ and $\mathrm{PGE}_{2}$ ) make it difficult to find genes universal for antiluteolytic mechanisms in these animal species.

Nevertheless, an examination of over 50 genes potentially involved in the process of porcine $\mathrm{CL}$ maintenance during early pregnancy helped to identify 14 genes with increased expression in CLs on Day 14 of pregnancy involved in steroidogenesis (i.e. scavenger receptor class $\mathrm{B}$, member 1 (SCARB1); STAR; hydroxydelta-5-steroid dehydrogenase, 3 beta and steroid delta-isomerase 1 (HSD3B1); LHCGR; nuclear receptor subfamily 5, group $\mathrm{A}$, member 1 (NR5A1); estrogen receptor 1 (ESR1); PGR; PGR membrane components $1 / 2(P G R M C 1 / 2)$ and in angiogenesis (i.e. angiopoietin 2 (ANGPT2); prostaglandin $\mathrm{F}$ synthase (PTGFS); hydroxyprostaglandin dehydrogenase 15-(NAP) $(H P G D)$; kinase insert domain receptor (KDR); VEGFR2; low density lipoprotein receptor $(L D L R)$; nuclear factor of kappa light polypeptide gene enhancer in B cells (NFKB1) and pentraxin 3 (PTX3)). Downregulated genes on Day 14 of pregnancy included EDN1, CYP19A1, ESR2, PTGS2, JUN and FOS (Fig. 1; Przygrodzka et al. 2015, 2016).

Factors involved in progesterone synthesis and metabolism, i.e., LHCGR, SCARB1, STAR and HSD3B1 were augmented on Day 14 vs Day 12 of gestation and the respective day of the estrous cycle. Also, expression of $N R 5 A 1$, a transcription activator of steroidogenic genes important for maintenance of progesterone secretion in gilts, was upregulated in CLs on Day 14 of gestation. These changes together with elevated abundance of PGRMC1 on the same day of pregnancy seem to be essential to support an anti-apoptotic mechanism mediated by progesterone in luteal tissue (Kowalik \& Kotwica 2008, Diaz et al. 2011). 
The observed relatively low expression of genes related to metabolism and action of $\mathrm{E}_{2}$ (CYP19A1 and ESR2) in CLs during early pregnancy is due to their paradoxical high expression in porcine CLs with acquired LS during induced (Diaz \& Wiltbank 2005) or spontaneous luteolysis (Przygrodzka et al. 2016). However, the abundance of CYP19A1 protein, sufficient to increase intraluteal content of $E_{2}$ and enhance conversion of testosterone to $E_{2}$ on Days 12 and 14 of gestation, suggest that luteal tissue of early pregnant pigs can produce $\mathrm{E}_{2}$.

Although increased EDN1 (Fig. 1) levels on Day 14 of the estrous cycle were suggested to play a role in development of LS in the pig (Zorrilla et al. 2010), a high abundance of HIF1A (Fig. 1) seems to act in the opposite way. Our recent in vitro study on the involvement of hypoxia and HIF1A in maintenance of porcine $\mathrm{CL}$ function revealed that $\mathrm{CoCl}_{2}$, a HIF1A activator, stimulated HIF1A, VEGFA and STAR expression only in CLs of cycling gilts. In addition, in silico analysis revealed the presence of HIF1A transcriptionbinding sites within the promoters of VEGFA and STAR genes. Other genes associated with luteal function maintenance (e.g., PGRMC1, EDN1) were also found to be potential targets of HIF1A. Thus, it seems likely that HIF1A can be another modulator of luteal function maintenance (E Przygrodzka, K Myszczynski \& AJ Ziecik, unpublished observations).

\section{MicroRNAs as new players in CL maintenance}

Since it was found that almost two-thirds of the genomic DNA is transcribed in eukaryotes, but less than $2 \%$ is translated into proteins, appreciation of the role of ncRNAs in regulating processes occurring in eukaryotes has dramatically increased (Rinn \& Chang 2012). However, the role of ncRNAs in luteal function maintenance remains poorly investigated. Among various types of ncRNAs the most studied are the miRNAs defined as short $\sim 22$-nt long RNA molecules that alter transcription and/or translation of mRNA molecules by binding mainly to its $3^{\prime}$ untranslated region (3'UTR). The general role of miRNAs in ovarian functions was stressed in studies performed on mice with deletion of $D I C E R$, an endonuclease responsible for cleavage of pre-miRNA to mature miRNA. This genetic modification led to inhibited follicle growth and reduced ovulation rate as well as faulty oocyte development and oviductal and uterine defects (Tang et al. 2007, Hong et al. 2008, Nagaraja et al. 2008). Global profiling of miRNAs during bovine and ovine CL development (Fiedler et al. 2008, McBride et al. 2012) and CL regression and rescue during pregnancy in cows (Ma et al. 2011, Maalouf et al. 2014) showed a number of differentially expressed miRNAs, but the specific roles of selected miRNAs have rarely been demonstrated. For instance, miR-378 was found to regulate apoptosis in bovine CLs (Ma et al. 2011),
miR-17-5p and miR-7p can regulate luteal angiogenesis in mice (Otsuka et al. 2008), while miR-96 was associated with luteal survival and steroidogenesis in human CLs (Mohammed et al. 2017). Our latest studies showed that miRNAs can also be involved in molecular and consequently hormonal changes in the porcine CL. Using microarrays, we identified several differentially expressed miRNAs in porcine CLs collected during the period of luteolysis (Day 14 of the estrous cycle) and maternal recognition of pregnancy (Day 14 of pregnancy). Among predicted targets of miRNAs upregulated during pregnancy, we found genes previously described as markers of luteolysis, e.g., EDN1, FOS, JUN, PTGS2, $F A S, E S R 2$. In contrast, miRNAs upregulated in CLs during luteolysis were found to target genes associated with luteal function maintenance, e.g., $P G R, P G R M C 2$, IGF2, FLT1, CREB, PTGER2 (Przygrodzka \& Kaczmarek 2016 unpublished data). Considering results of global studies performed in other animal species and with porcine CLs, it is likely that some miRNAs can have a supportive role in the luteolytic or luteotropic actions of primary factors regulating luteal function. That conclusion is further supported by our in vitro studies on luteal tissue slices, showing $\mathrm{E}_{2}$, a luteotropic conceptusderived signal in pigs, to be a factor able to upregulate the expression of miRNAs targeting genes involved in progesterone metabolism (Przygrodzka \& Kaczmarek 2017 unpublished data). These results shed new light on the role of miRNAs in a novel molecular mechanism supporting the luteotropic action of conceptus-derived signals during early pregnancy.

\section{Two-signal switch hypothesis}

Recently, we proposed the 'two-signal switch hypothesis' to highlight the importance of post $\mathrm{PGF}_{2 \alpha}$ and $\mathrm{PGE}_{2}$ receptor signaling pathways activation in CLs during luteolysis and $\mathrm{CL}$ rescue during maternal recognition of pregnancy in the pig (Ziecik et al. 2017). The updated version of the hypothesis is presented in Fig. 2. After acquisition of LS by CLs on Days 12-14 of the estrous cycle due to the influence of cytokines, e.g., TNF $\alpha$, IFN $\gamma$ and EDN1 (forming the 'luteolytic switch'), luteal cells begin to be sensitive to the luteolytic activity of $\mathrm{PGF}_{2 \alpha}$. As a result, the post PTGFR signaling pathway activates two phospholipase C (PLC) pathways through: 1) diacylglycerol (DAG) and PKC, leading to inhibition of cAMP production and 2) inositol 1,4,5-triphosphate (IP3) and $\mathrm{Ca}^{2+}$ activating proto-oncogene protein-serine threonine kinase (RAF1) and the downstream RAF/MEK/ ERK signaling cascade in the cytoplasm. Phosphorylated ERK1/2 proteins are translocated into the nucleus and induce both FOS and JUN and other proto-oncogenes, contributing to AP1 transcription factor dimers formation. Furthermore, this leads to transcription activation of genes involved in functional and structural luteolysis. Before the 'luteolytic switch' is triggered, the porcine 


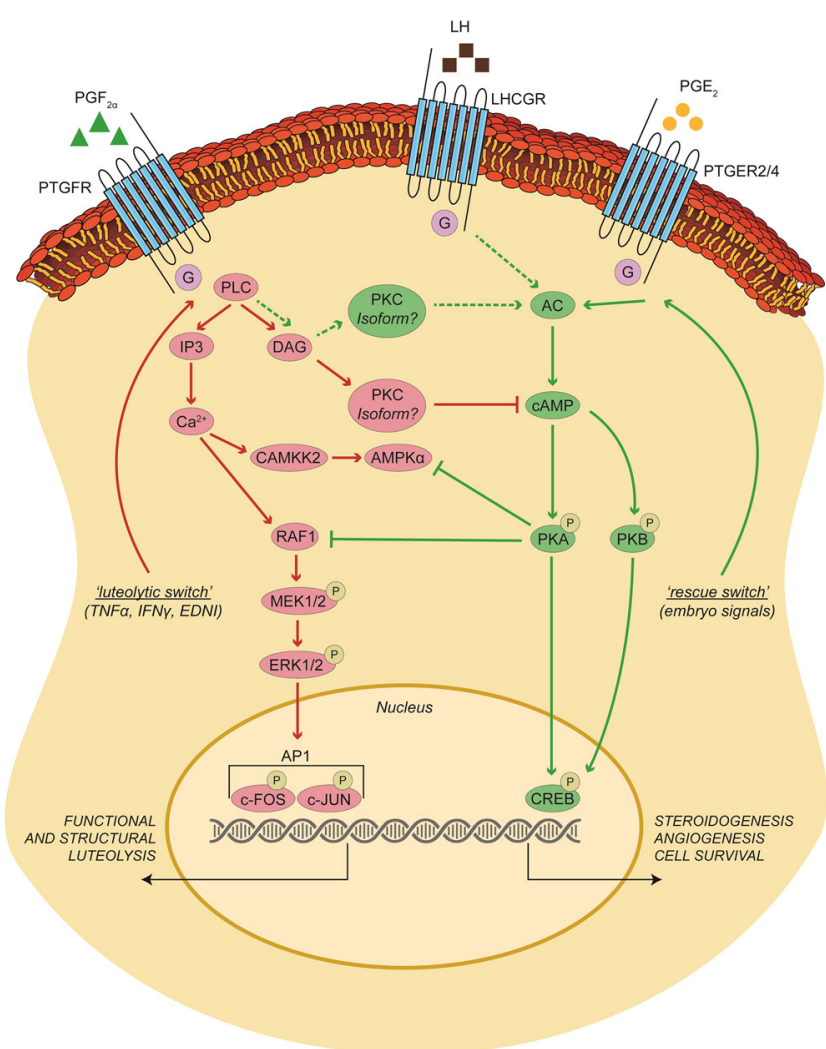

Figure 2 The updated version of the 'two signal switch' hypothesis of $\mathrm{PGF}_{2 \alpha}$ and $\mathrm{PGE}_{2}$ involvement in regression or rescue of porcine $\mathrm{CL}$. Before the luteolytic sensitivity (LS) of luteal tissue is reached about Day 12 of estrous cycle $\mathrm{PGF}_{2 \alpha}$ through its specific transmembrane G-protein coupled receptor (PTGFR) amplifies LH - stimulated cAMP accumulation (dotted green arrows). After acquisition of LS by mediators of luteal regression the 'luteolytic switch' is turn on (red pathway) changing the post-PTGRF sequence of events leading to inhibition of CAMP accumulation and luteolysis through DAG-PKC and IP3-ERK1/2 subpathways respectively. During early pregnancy, however, the embryo signals (estradiol $17 \beta$ and $\mathrm{PGE}_{2}$ ) of conceptuses and endometrial origin turn the 'rescue switch' on (green solid arrows) leading to induction of the post-PTGER2/4 pathway and activation of both protein kinases PKA, PKB and activation of CREB for maintenance of steroidogenesis, angiogenesis and cell survival. Simultaneously PKA inhibits RAF, and turns the 'luteolytic switch' off. AC, adenyl cyclase; cAMP, cyclic adenosine monophosphate; CREB, cAMP response element-binding protein; DAG, diacylglycerol; IP3, inositol triphosphate; ERK1/2, extracellular signal-regulated kinase 1/2; PKC, protein kinase C; PLC, phospolipase C; RAF, proto-oncogene serine/threonine-protein kinase (figure modified from Ziecik et al. 2017).

$\mathrm{CL}$ is supported by synergistic luteotropic actions of $\mathrm{LH}$ and $\mathrm{PGF}_{2 \alpha}$ on CAMP accumulation. However, a lack of embryo signals and LS acquisition unavoidably leads to regression of the luteal tissue.

In contrast, during maternal recognition and establishment of pregnancy, embryo signals, estradiol $\left(E_{2}\right)$ and $\mathrm{PGE}_{2}$ ('rescue switch') through its $\mathrm{PGE}_{2}$ receptors (PTGER2/4), activate PKA and inhibit (1) AMPK (AMPactivated protein kinase) and hormone-sensitive lipase, reducing cholesterol availability for progesterone synthesis (Talbott \& Davis 2017) and (2) RAF1 (Bos et al. 2004). Together, $\mathrm{LH}$ and $\mathrm{PGE}_{2}$ increase the availability of cholesterol for progesterone synthesis. At the same time, phosphorylation of PKA, PKB and CREB by PGE supports maintenance of angiogenesis, steroidogenesis and cell survival in the CL. Interestingly, the results of recent report on mechanisms for rescue of bovine $\mathrm{CL}$ during early pregnancy (Ochoa et al. 2018) also strongly support a luteoprotective role of $\mathrm{PGE}_{2}$.

\section{CL function during pregnancy Role of $\mathbf{L H}$ and prolactin}

It was suggested that later in pregnancy, prolactin can maintain luteal function in hypophysectomized gilts (Du Mesnil du Buisson \& Denamur 1968, Li et al. 1989). However, it is not clear whether the influence of $\mathrm{LH}$ on $C L$ function is ever lost during pregnancy, since temporal interrelationships between pulses in circulating $\mathrm{LH}$ and progesterone levels have been demonstrated as late as on Day 90 (Parvizi et al. 1976).

The first reports on $\mathrm{LH}$ concentrations during various periods of pregnancy in pigs were fragmentary and contradictory (Tilson et al. 1970, Guthrie et al. 1972, Parvizi et al. 1976) until the profile of plasma LH during the course of pregnancy in the pig was described in detail (Ziecik et al. 1983). It was shown that from the first 6-7 days of gestation until parturition, $\mathrm{LH}$ release showed rhythmic pulses throughout pregnancy with decreasing amplitudes from Days 12 to 24 until parturition. The levels and patterns of $\mathrm{LH}$ secretion in early and mid-gestation were similar to the mid-luteal phase of the estrous cycle.

The plasma LH fluctuated in a pulsatile manner throughout gestation with declining amplitude toward parturition and a significant correlation between the decrease in LH concentrations and the day of gestation was determined: $y=1.758-0.0088 x$, where variable ' $x$ ' is a day of gestation (Ziecik et al. 1983). It is possible that increasing levels of estrogens during pregnancy (Robertson \& King 1974) can negatively influence the basal LH level and the magnitude of its fluctuations. The reduction in LH levels may cause a simultaneous decrease in the concentration of progesterone (Guthrie et al. 1972).

The onset of prolactin dependency is supposed to be associated with an increased content of prolactin receptors in CLs during early pregnancy (Jammes et al. 1985). Our results indicated that decreasing the concentration of blood plasma prolactin by treatment with bromocriptine (inhibitor of prolactin secretion) is not mandatory for the weakening of $C L$ steroidogenesis during mid-pregnancy (Szafranska \& Ziecik 1990a) and in the second half of pregnancy in pigs (Szafranska \& Ziecik 1990b). It is possible that pregnant gilts have a 
specific substitute mechanism of compensation at the level of the hypothalamus and/or pituitary, developed to maintain $\mathrm{CL}$ function during pregnancy if $\mathrm{LH}$ or prolactin deficiency occurs. It seems likely that pregnancy stage has no effect on prolactin concentrations until shortly before term, when a dramatic surge of prolactin occurs presumably due to lactogenesis (Dusza \& Krzymowska 1981). Prolactin together with other metabolic hormones, growth factor $(\mathrm{GH})$ and insulin-like growth factor 1 (IGF1), may act synergistically to increase progesterone secretion by porcine luteal cells (Yuan \& Lucy 1996).

\section{Strategies to support enhanced $C L$ function during pregnancy}

The majority of studies concerning CL function during pregnancy were focused on the period of maternal recognition of pregnancy and implantation, i.e., Days 12-18 of pregnancy. Some reports extended observations to Day 30 of pregnancy, since the highest embryonic mortality (20-30\%) in pigs happens between Days 12 and 30 of pregnancy (Lambert et al. 1991). According to Jindal et al. (1997), progesterone is important in mediating the supply of nutrients influencing embryonic survival in gilts. Thus, to date, many attempts have been undertaken to stimulate luteal function in order to reduce early embryo mortality by application of various hormones that enhance luteal function in pigs. However, multiple injections of hCG, a known analog of $\mathrm{LH}$, during the first 8 days of gestation (Stone et al. 1987) or a single administration of hCG after Day 12 (Tilton et al. 1989, Bolzan et al. 2013) did not affect the level of progesterone in the blood plasma of pigs. A single injection of hCG on Day 12 of pregnancy elevated $E_{2}$ concentration and increased expression of STAR, accompanied by reduced levels of early apoptotic luteal cells and elevated percentages of live luteal cells in CLs on Day 30 of pregnancy (Bolzan et al. 2013). It is worth mentioning that resorption of all fetuses on Day 30 of pregnancy did not affect the level of progesterone in blood until Day 60 of pregnancy, which may suggest that fetus-derived signals are not necessary to maintain $\mathrm{CL}$ function between Day 30 and 60 of pregnancy in pigs (Webel et al. 1975).

\section{Concluding remarks}

The earlier fundamental theories of maternal recognition of pregnancy based on redirection and cessation of $\mathrm{PGF}_{2 \alpha}$ supply to CLs have not considered the overcoming of LS acquisition during the process of $\mathrm{CL}$ rescue after Day 12 p.c. This complex process initiated by embryo signals, mainly $E_{2}$ and $\mathrm{PGE}_{2}$, depends on cooperation between many pleiotropic factors determining luteal function maintenance. Overcoming of LS to $\mathrm{PGF}_{2 \alpha}$ also relies on the change of the 'luteolytic' to the 'luteotropic' role of this prostaglandin to support $\mathrm{CL}$ function, besides the proven and already known actions of $\mathrm{LH}$ and $\mathrm{PGE}_{2}$ during early pregnancy.

Our 'two signal switch' hypothesis concerning participation of $\mathrm{PGF}_{2 \alpha}$ and $\mathrm{PGE}_{2}$ and their post receptor signaling systems, activated in CLs during luteolysis and during the process of luteal rescue, is based on available knowledge and our recent studies at the molecular level. It also shows the complexity of the interactions driving luteal control during the most sensitive periods of the life cycle of CLs: regression and rescue.

Complete understanding of the mechanisms driving luteal function in pigs and other species requires establishment of a sequence hierarchy and particular timing of molecular interrelationship between many mediators of the CL life span (development, regression, rescue and maintenance) as well as their endocrine and paracrine actions at the systemic, local and subcellular levels.

\section{Declaration of interest}

The authors declare that there is no conflict of interest that could be perceived as prejudicing the impartiality of this review.

\section{Funding}

This research did not receive any specific grant from any funding agency in the public, commercial or not-for-profit sector.

\section{Acknowledgments}

Some research described in the review was supported by the statutory Fund of IARFR in Olsztyn (Poland). The authors thank J Murawska-Kempa for her helpful assistance in typing the manuscript.

\section{References}

Anderson LL, Dyck GW, Mori H, Henricks DM \& Malapy RM 1967 Ovarian function in pigs following hypophysical stalk transaction or hypophysectomy. American Journal of Physiology 212 1188-1194.

Bazer FW \& Thatcher WW 1977 Theory of maternal recognition of pregnancy in swine based on estrogen controlled endocrine versus exocrine secretion of prostaglandin F2alpha by the uterine endometrium. Prostaglandins $14 \quad 397-400 . \quad$ (https://doi.org/10.1016/00906980(77)90185-X)

Bazer FW, Geisert RD, Thatcher WW \& Roberts RM 1982 The establishment and maintenance of pregnancy. In Control of Reproduction in the Pig, pp 227-252. Eds DIA Cole \& GR Foxcroft. London: Butterworth Co.

Belt WD, Anderson LL, Cavazos LF, \& Melampy RM 1971 Cytoplasmic granules and relaxin levels in porcine corpora lutea. Endocrinology $\mathbf{9 8}$ 1-10. (https://doi.org/10.1210/endo-89-1-1)

Blitek A \& Ziecik AJ 2005 Effect of LH on prostaglandin $F_{2 \alpha}$ and prostaglandin $\mathrm{E}_{2}$ secretion by cultured porcine endometrial cells. Reproduction 130 105-112. (https://doi.org/10.1530/rep.1.00639)

Bolzan E, Andronowska A, Bodek G, Morawska-Pucinska E, Krawczynski K, Dabrowski A \& Ziecik AJ 2013 The novel effect of hCG administration on luteal function maintenance during the estrous cycle/pregnancy and early embryo development in the pig. Polish Journal of Veterinary Sciences 116 323-332. 
Bos CL, Richel DJ, Ritsema T, Peppelenbosch MP \& Versteeg HH 2004 Prostanoids and prostanoid receptors in signal transduction. International Journal of Biochemistry and Cell Biology 36 1187-1205. (https://doi. org/10.1016/j.biocel.2003.08.006)

Brinkley HJ 1981 Endocrine signaling and female reproduction. Biology of Reproduction 24 22-43. (https://doi.org/10.1095/biolreprod24.1.22)

Brussow K-P, Schneider F \& Nurnberg G 2001 Alternation of gonadotrophin and steroid hormone release, and ovarian function by a GnRH antagonist in gilts. Animal Reproduction Sciences 66 117-128. (https:// doi.org/10.1016/S0378-4320(01)00093-8)

Buhr MM 1987 Effect of lipoproteins and luteinizing hormone on progesterone production by large and small luteal cells throughout the porcine estrous cycle. Journal of Animal Science 65 1027-1033. (https:// doi.org/10.2527/jas1987.6541027x)

Carnahan KG, Prince BC \& Mirando MA 1996 Exogenous oxytocin stimulates uterine secretion of prostaglandin F2 alpha in cyclic and early pregnant swine. Biology of Reproduction 55 838-843. (https://doi. org/10.1095/biolreprod55.4.838)

Chang J, Frandsen S \& Gadsby JE 2017 Prostaglandin synthesis by the porcine corpus luteum: effect of tumor necrosis factor- $\alpha$. Domestic Animal Endocrinology 58 53-62. (https://doi.org/10.1016/j. domaniend.2016.07.001)

Christenson LK, Farley DB, Anderson LH \& Ford SP 1994 Luteal maintenance during early pregnancy in the pig: role for prostaglandin E2. Prostaglandins 47 61-75. (https://doi.org/10.1016/0090-6980(94)90075-2)

Davis JS \& Rueda BR 2002 The corpus luteum: an ovarian structure with maternal instincts and suicidal tendencies. Frontiers in Bioscience 7 d1949-d1978. (https://doi.org/10.2741/davis1)

Diaz FJ \& Wiltbank MC 2005 Acquisition of luteolytic capacity involves differential regulation by prostaglandin $\mathrm{F} 2 \mathrm{a}$ of genes involved in progesterone biosynthesis in the porcine corpus luteum. Domestic Animal Endocrinology 28 172-189. (https://doi.org/10.1016/j. domaniend.2004.08.002)

Diaz FJ, Crenshaw TD \& Wiltbank MC 2000 Prostaglandin F(2alpha) induces distinct physiological responses in porcine corpora lutea after acquisition of luteolytic capacity. Biology of Reproduction 63 1504-1512. (https://doi.org/10.1095/biolreprod63.5.1504)

Diaz FJ, Luo W \& Wiltbank MC 2011 Effect of decreasing intraluteal progesterone on sensitivity of the early porcine corpus luteum to the luteolytic actions of prostaglandin F2alpha. Biology of Reproduction $\mathbf{8 4 1}$ 26-33. (https://doi.org/10.1095/biolreprod.110.084368)

Du Mesnil Buisson F \& Leglise PC 1963 Effet de I'hypophysectomie sue les corps jaunes de la truie. Resultatas preliminaires. Comptes Rendus Hebdomadaires des Séances de l'Académie des Sciences 257 261-263.

Du Mesnil du Buisson F \& Denamur R 1968 Mécanismes du controle de la fonction lutéal chez la truie, la brebis et la vache. In Proceedings of $3 r d$ International Congress of Endocrinology, Mexico (International Congress Series, No 184), pp 927-934. Eds L Gual and FJ Ebling. Amsterdam: Excerpta Medica.

Dusza L \& Krzymowska H 1981 Plasma prolactin levels in sows during pregnancy, parturition and early lactation. Journal of Reproduction and Fertility 61 131-134. (https://doi.org/10.1530/jrf.0.0610131)

Ellicott AR \& Dziuk PJ 1973 Minimum daily dose of progesterone and plasma concentration for maintenance of pregnancy in ovariectomized gilts. Biology of Reproduction 90 300-304. (https://doi.org/10.1093/ biolreprod/9.3.300)

Fiedler SD, Carletti MZ, Hong X \& Christenson LK 2008 Hormonal regulation of MicroRNA expression in periovulatory mouse mural granulosa cells. Biology of Reproduction 79 1030-1037. (https://doi. org/10.1095/biolreprod.108.069690)

Ford SP, Magness RR, Farley DB \& Van Orden DE 1982 Local and systemic effects of intrauterine estradiol-17 beta on luteal function of nonpregnant sows. Journal of Animal Science 55 657-664. (https://doi.org/10.2527/ jas1982.553657x)

Franczak A, Wojciechowicz B \& Kotwica G 2013 Transcriptomic analysis of the porcine endometrium during early pregnancy and the estrus cycle. Reproductive Biology 13 229-237. (https://doi.org/10.1016/j. repbio.2013.07.001)

Gadsby JE, Balapure AK, Britt JH \& Fitz TA 1990 Prostaglandin F2 alpha receptors on enzyme dissociated pig luteal cells throughout the estrous cycle. Endocrinology 126 787-795. (https://doi.org/10.1210/endo-1262-787)
Gadsby JE, Lovdal JA, Britt JH \& Fitz TA 1993 Prostaglandin F2 alpha receptor concentrations in corpora lutea of cycling, pregnant, and pseudopregnant pigs. Biology of Reproduction 49 604-608. (https://doi. org/10.1095/biolreprod49.3.604)

Garverick HA, Polge C \& Flint APF 1982 Oestradiol administration raises luteal $\mathrm{LH}$ receptor levels in intact and hysteronectomized pigs. Journal of Reproduction and Fertility 66 371-377. (https://doi.org/10.1530/ jrf.0.0660371)

Guthrie HD \& Bolt DJ 1983 Changes in plasma estrogen, luteinizing hormone, follicle stimulating hormone and 13,14-dihydro-15-ketoprostaglandin $F_{2 \alpha}$ during blockade of luteolysis in pigs after human chorionic gonadotropin treatment. Journal of Animal Science $\mathbf{5 2}$ 993-1000. (https://doi.org/10.2527/jas1983.574993x)

Guthrie HD, Henricks DM \&, Handlin DL 1972 Plasma estrogen, progesterone and luteinizing hormone prior to estrus and during early pregnancy in pigs. Endocrinology 91 675-679. (https://doi.org/10.1210/ endo-91-3-675)

Hong X, Luense LJ, McGinnis LK, Nothnick WB \& Christenson LK 2008 Dicer1 is essential for female fertility and normal development of the female reproductive system. Endocrinology 149 6207-6212. (https://doi. org/10.1210/en.2008-0294)

Hoover DJ \& Young EP 1979 Luteinizing hormone (LH) secretion patterns in nonpregnant sows. Biology of Reproduction 20 (Supplement 1) $42 \mathrm{~A}$ (Abstr).

Jammes H, Schirar A \& Dijane J 1985 Differential patterns in luteal prolactin and LH receptors during pregnancy in sows and ewes. Journal of Reproduction and Fertility 73 27-35. (https://doi.org/10.1530/ jrf.0.0730027)

Jindal R, Cosgrove JR \& Foxcroft GR 1997 Progesterone mediates nutritionally induced effects on embryonic survival in gilts. Journal of Animal Science 75 1063-1070. (https://doi.org/10.2527/1997.7541063x)

Kaczmarek MM, Kowalczyk AE, Waclawik A, Schams D \& Ziecik AJ 2007 Expression of vascular endothelial growth factor and its receptors in the porcine corpus luteum during the estrous cycle and early pregnancy. Molecular Reproduction and Development 74 730-739. (https://doi. org/10.1002/mrd.20638)

Kaczmarek MM, Kiewisz J, Schams D \& Ziecik AJ 2009 Expression of VEGF-receptor system in conceptus during peri-implantation period and endometrial and luteal expression of soluble VEGFR-1 in the pig. Theriogenology 71 1298-1306. (https://doi.org/10.1016/j. theriogenology.2008.12.022)

Kiewisz J, Krawczynski K, Lisowski P, Blitek A, Zwierzchowski L Ziecik AJ \& Kaczmarek MM 2014 Global profiling of porcine endometria on Days 12 and 16 of the estrous cycle and pregnancy. Theriogenology 82 897-909. (https://doi.org/10.1016/j.theriogenology.2014.07.009)

Kotwica G, Franczak A, Okrasa S \& Kotwica J 1999 Effect of an oxytocin antagonist on prostaglandin $\mathrm{F}_{2 \alpha}$ secretion and the course of luteolysis in sows. Acta Veterinaria Hungarica 47 249-262. (https://doi. org/10.1556/004.47.1999.2.10)

Kowalczyk A E, Kaczmarek M M, Schams D \& Ziecik A J 2008 Effect of prostaglandin E2 and tumor necrosis factor a on theVEGF-receptor system expression in cultured porcine luteal cells. Molecular Reproduction and Development 75 1558-1566. (https://doi.org/10.1002/mrd.20897)

Kowalik MK \& Kotwica J 2008 Progesterone receptor membrane component 1 (PGRMC1) gene expression in corpus luteum during the estrous cycle in cows. Reproductive Biology 8 291-297. (https://doi. org/10.1016/S1642-431X(12)60019-9)

Krzymowski T \& Stefanczyk-Krzymowska S 2004 The oestrous cycle and early pregnancy - a new concept of local endocrine regulation. Veterinary Journal 168 285-296. (https://doi.org/10.1016/j.tvjl.2003.10.010)

Lambert E, Williams DH, Lynch PB, Hanrahan TJ, McGeady TA, Austin FH, Boland MP \& Roche JF 1991 The extent and timing of prenatal loss in gilts. Theriogenology 36 655-665. (https://doi.org/10.1016/0093691X(91)90403-Z)

LaVoie HA 2017 Transcriptional control of genes mediating ovarian follicular growth, differentiation, and steroidogenesis in pigs. Molecular Reproduction and Development 84 788-801 (https://doi.org/10.1002/ mrd.22827)

Li YF, Molina JR, Klindt J, Bolt DJ \& Andreson LL 1989 Prolactin maintains relaxin and progesterone secretion by aging corpora lutea after hypophysial stalk transaction or hypophysectomy. Endocrinology 124 1294-1304. (https://doi.org/10.1210/endo-124-3-1294) 
Ma T, Jiang H, Gao Y, Zhao Y, Dai L, Xiong Q, Xu Y, Zhao Z \& Zhang J 2011 Microarray analysis of differentially expressed microRNAs in nonregressed and regressed bovine corpus luteum tissue; microRNA-378 may suppress luteal cell apoptosis by targeting the interferon gamma receptor 1 gene. Journal of Applied Genetics 52 481-486. (https://doi. org/10.1007/s13353-011-0055-z)

Maalouf SW, Liu WS, Albert I \& Pate JL 2014 Regulating life or death: potential role of microRNA in rescue of the corpus luteum. Molecular and Cellular Endocrinology 398 78-88. (https://doi.org/10.1016/j. mce.2014.10.005)

Mamluk R, Defer N, Hanoune J \& Meidan R 1999 Molecular identification of adenyl cyclase 3 in bovine corpus luteum and its regulation by prostaglandin F2 $\alpha$-induced signaling pathways. Endocrinology $\mathbf{1 4 0}$ 4601-4608. (https://doi.org/10.1210/endo.140.10.7099)

McBride D, Carré W, Sontakke SD, Hogg CO, Law A, Donadeu FX \& Clinton M 2012 Identification of miRNAs associated with the follicularluteal transition in the ruminant ovary. Reproduction 144 221-233. (https://doi.org/10.1530/REP-12-0025)

Moeljono MPE, Thatcher WW, Bazer FW, Frank M, Owens LJ \& Wilcox CJ 1977 A study of prostaglandin F2alpha as the luteolysin in swine: II. Characterization and comparison of prostaglandin F, estrogens and progestin concentrations in utero-ovarian vein plasma of nonpregnant and pregnant gilts. Prostag/andins 14 543-555. (https://doi. org/10.1016/0090-6980(77)90268-4)

Mohammed BT, Sontakke SD, Ioannidis J, Duncan WC \& Donadeu FX 2017 The adequate corpus luteum: miR-96 promotes luteal cell survival and progesterone production. Journal of Clinical Endocrinology and Metabolism 102 2188-2198. (https://doi.org/10.1210/jc.2017-00259)

Nagaraja AK, Andreu-Vieyra C, Franco HL, Ma L, Chen R, Han DY, Zhu H, Agno JE, Gunaratne PH, DeMayo FJ et al. 2008 Deletion of Dicer in somatic cells of the female reproductive tract causes sterility. Molecular Endocrinology 22 2336-2352. (https://doi.org/10.1210/me.2008-0142)

Niswender GD, Juengel JL, Silva PJ, Rollyson MK \& McIntush EW 2000 Mechanisms controlling the function and life span of the corpus luteum. Physiological Reviews 80 1-29. (https://doi.org/10.1152/ physrev.2000.80.1.1)

Ochoa JC, Penagaricano F, Baez GM, Melo LF, Motta JLC, GarciaGuerra A, Meidan R, Pineheiro Ferreira J, Sartori R \& Wiltbank MC 2018 Mechanisms for rescue of corpus luteum during pregnancy: gene expression in bovine corpus luteum following intrauterine pulses of prostaglandins $\mathrm{E}_{1}$ and $\mathrm{F}_{2 \alpha}$. Biology of Reproduction. (https://doi. org/10.1093/biolre/iox183)

Okano A, Kishi H, Takahashi H \& Takahashi M 2006 Tumor necrosis factoralpha induces apoptosis in cultured porcine luteal cells. Journal of Reproduction and Development 52 301-306. (https://doi.org/10.1262/ jrd.17045)

Østrup E, Bauersachs S, Blum H, Wolf E \& Hyttel P 2010 Differential endometrial gene expression in pregnant and nonpregnant sows. Biology of Reproduction 83 277-285. (https://doi.org/10.1095/ biolreprod.109.082321)

Otsuka M, Zheng M, Hayashi M, Lee J-D, Yoshino O, Lin S \& Han J 2008 Impaired microRNA processing causes corpus luteum insufficiency and infertility in mice. Journal of Clinical Investigations 118 1944-1954. (https://doi.org/10.1172/JCl33680)

Parvizi N, Elsaesser F, Schmidt D \& Ellendorff E 1976 Plasma luteinizing hormone and progesterone in the adult female pigs during the oestrous cycle, late pregnancy and lactation, and after ovariectomy and pentobarbitone treatment. Journal of Endocrinology 69 193-203. (https://doi.org/10.1677/joe.0.0690193)

Przygrodzka E, Lopinska M \& Ziecik AJ 2014 Precision-cut luteal slices: a promising approach for studying luteal function in pigs. Reproductive Biology 14 243-247. (https://doi.org/10.1016/j.repbio.2014.04.001)

Przygrodzka E, Witek KJ, Kaczmarek MM, Andronowska A \& Ziecik AJ 2015 Expression of factors associated with apoptosis in the porcine corpus luteum throughout the luteal phase of the estrous cycle and early pregnancy: Their possible involvement in acquisition of luteolytic sensitivity. Theriogenology 83 535-545. (https://doi.org/10.1016/j. theriogenology.2014.10.016)

Przygrodzka E, Kaczmarek MM, Kaczynski P \& Ziecik AJ 2016 Steroid hormones, prostanoids, and angiogenic systems during rescue of the corpus luteum in pigs. Reproduction 15 135-147. (https://doi. org/10.1530/REP-15-0332)
Rinn JL \& Chang HY 2012 Genome regulation by long noncoding RNAs. Annual Review of Biochemistry 8 145-166. (https://doi.org/10.1146/ annurev-biochem-051410-092902)

Robertson HA \& King GJ 1974 Plasma concentrations of progesterone, oestrone, oestradiol-17 $\beta$ and of oestrone sulphate in the pig at implantation, during pregnancy and at parturition. Journal of Reproduction and Fertility 40 133-141. (https://doi.org/10.1530/ jrf.0.0400133)

Romero JJ, Antoniazzi AQ, Smirnova NP, Webb BT, Yu F, Davis Js \& Hansen TR 2013 Pregnancy-associated genes contribute to antiluteolytic mechanisms in ovine corpus luteum. Physiological Genomics $\mathbf{4 5}$ 1095-1108. (https://doi.org/10.1152/physiolgenomics.00082.2013)

Sakumoto R \& Okuda K 2004 Possible actions of tumor necrosis factoralpha in ovarian function. Journal of Reproduction and Development $\mathbf{5 0}$ 39-46. (https://doi.org/10.1262/jrd.50.39)

Sakumoto R, Komatsu T, Kasuya E, Saito T \& Okuda K 2006 Expression of mRNAs for interleukin-4, interleukin- 6 and their receptors in porcine corpus luteum during the estrous cycle. Domestic Animal Endocrinology 31 246-257. (https://doi.org/10.1016/j.domaniend.2005.11.001)

Skarzynski DJ, Bah MM, Deptula KM, Woclawek-Potocka I, Korzekwa A, Shibaya M, Pilawski W \&Okuda K 2003 Roles of tumor necrosis factoralpha of the estrous cycle in cattle: an in vivo study. Biology of Reproduction 69 1907-1913. (https://doi.org/10.1095/biolreprod.103.016212)

Stefanczyk-Krzymowska S, Wasowska B, Chłopek J, Gilun P, Grzegorzewski W \& Radomski M 2006 Retrograde and local destination transfer of uterine prostaglandin E2 in early pregnant sow and its physiological consequences. Prostaglandins and Other Lipid Mediators 81 71-79. (https://doi.org/10.1016/j.prostaglandins.2006.07.004)

Stepien A, Shemesh M \& Ziecik AJ 1999 Luteinizing hormone receptor kinetic and $\mathrm{LH}$-induced prostaglandin production throughout the oestrous cycle in porcine endometrium. Reproduction Nutrition and Development 39 663-674. (https://doi.org/10.1051/rnd:19990512)

Stone BA, Heap PA \& Seamark RF 1987 Changes in peripheral progestagen levels in early pregnant gilts following injection of human chorionic gonadotrophin. Journal of Endocrinology 115 161-167. (https://doi. org/10.1677/joe.0.1150161)

Szafranska B \& Ziecik A 1989 Active and passive immunization aganist luteinizing hormone in pigs. Acta Physiologica Hungarica 74 253-258.

Szafranska B \& Ziecik AJ 1990a Effect of bromocriptine administration during mid-pregnancy on the ovary function in the pig. Experimental and Clinical Endocrinology 96 317-320. (https://doi. org/10.1055/s-0029-1211026)

Szafranska B \& Ziecik AJ 1990b Effect of bromocriptine administration on maintenance of late pregnancy in the pig. Experimental and Clinical Endocrinology 96 321-324. (https://doi.org/10.1055/s-0029-1211027)

Talbott H \& Davis JS 2017 Lipid droplets and metabolic pathways regulate steroidogenesis in the corpus luteum. In The Life Cycle of the Corpus Luteum, pp 57-78. Ed R Meidan. Switzerland: Springer International Publishing.

Tang F, Kaneda M, O'Carroll D, Hajkova P, Barton SC, Sun YA, Lee C, Tarakhovsky A, Lao K \& Surani MA 2007 Maternal microRNAs are essential for mouse zygotic development. Genes and Development 21 644-648. (https://doi.org/10.1101/gad.418707)

Tilson SA, Erb RE \& Niswender GD 1970 Comparison of luteinizing hormone and progesterone in blood and metabolites of progesterone in urine of domestic sows during the estrous cycle and early pregnancy. Journal of Animal Science 30 795-805. (https://doi.org/10.2527/ jas1970.305795x)

Tilton JE, Schmidt AE, Weigl RM \& Ziecik AJ 1989 Ovarian steroid secretion changes after hCG stimulation in early pregnant pigs. Theriogenology 32 623-631. (https://doi.org/10.1016/0093-691X(89)90283-5)

Van de Wiel DFM, Erkens J, Koops W, Elene V \& van Landeghem AAJ 1981 Periestrous and midluteal time courses of circulating LH, FSH, prolactin, estradiol-17 $\beta$ and progesterone in the domestic pigs. Biology of Reproduction 24 223-233. (https://doi.org/10.1095/biolreprod24.2.223)

Waclawik A \& Ziecik AJ 2007 Differential expression of prostaglandin (PG) synthesis enzymes in conceptus during peri-implantation period and endometrial expression of carbonyl reductase/PG 9-ketoreductase in the pig. Journal of Endocrinology 194 499-510. (https://doi.org/10.1677/ JOE-07-0155)

Waclawik A, Blitek A \& Ziecik AJ 2010 Oxytocin and tumor necrosis factor $\alpha$ stimulate expression of prostaglandin E2 synthase and secretion of 
prostaglandin E2 by luminal epithelial cells of the porcine endometrium during early pregnancy. Reproduction 140 613-622. (https://doi. org/10.1530/REP-10-0092)

Wacławik A, Kaczmarek MM, Blitek A, Kaczynski P \& Ziecik AJ 2017 Embryo-maternal dialogue during pregnancy establishment and implantation in the pig. Molecular Reproduction and Development 84 842-855. (https://doi.org/10.1002/mrd.22835)

Wasielak M, Glowacz M, Kaminska K, Waclawik A \& Bogacki M 2008 The influence of embryo presence on prostaglandins synthesis and prostaglandin E2 and F2 $\alpha$ content in corpora lutea during periimplantation period in the pig. Molecular Reproduction and Development 75 1208-1216. (https://doi.org/10.1002/mrd.20862)

Webel SK, Reimers TJ \& Dziuk PJ 1975 The lack of relationship between plasma progesterone levels and number of embryos and their survival in the pig. Biology of Reproduction 13 177-186. (https://doi.org/10.1095/ biolreprod13.2.177)

Wiepz GL, Wiltbank MC, Nett TM, Niswender GD \& Sawyer HR 1992 Receptors for prostaglandin F2 alpha and E2 in ovine corpora lutea during maternal recognition of pregnancy. Biology of Reproduction 47 984-991. (https://doi.org/10.1095/biolreprod47.6.984)

Woody CO, First NL \& Pope AL 1967 Effect of exogenous progesterone on estrous cycle length. Journal of Animal Science 26 139-141. (https://doi. org/10.2527/jas1967.261139x)

Wuttke W, Spiess S, Knoke I, Pitzel L, Leonhardt S \& Jarry H 1998 Synergistic effects of prostaglandin F2alpha and tumor necrosis factor to induce luteolysis in the pig. Biology of Reproduction 58 1310-1315. (https://doi.org/10.1095/biolreprod58.5.1310)

Yuan W \& Lucy MC. 1996 Messenger ribonucleic acid expression for growth hormone receptor, luteinizing hormone receptor, and steroidogenic enzymes during the estrous cycle and pregnancy in porcine and bovine corpora lutea. Domestic Animal Endocrinology 13 431-444. (https://doi. org/10.1016/0739-7240(96)00073-2)

Zannoni A, Bernardini C, Rada T, Ribeiro LA, Forni M \& Bacci ML 2007 Prostaglandin F2-alpha receptor (FPr) expression on porcine corpus luteum microvascular endothelial cells (pCL-MVECs). Reproductive Biology and Endocrinology 20 5-31. (https://doi.org/10.1186/14777827-5-31)

Zhang H, Wang S, Liu M, Zhang A, Wu Z, Zhang Z \& Li J 2013 Differential gene expression in the endometrium on gestation day 12 provides insight into sow prolificacy. BMC Genomics 14 45. (https://doi. org/10.1186/1471-2164-14-45)

Zhao Y, Burbach JA, Roby KF, Terranova PF \& Brannian JD 1998 Macrophages are the major source of tumor necrosis factor-alpha in the porcine corpus luteum. Biology of Reproduction 59 1385-1391. (https:// doi.org/10.1095/biolreprod59.6.1385)
Ziecik AJ 2002 Old, new and the newest concepts of inhibition of luteolysis during early pregnancy in pig. Domestic Animal Endocrinology 23 265-275. (https://doi.org/10.1016/S0739-7240(02)00162-5)

Ziecik A Shaw HJ \& Flint APF 1980 Luteal receptors during the estrous cycle and early pregnancy in the pig. Journal of Reproduction and Fertility 60 129-137. (https://doi.org/10.1530/jrf.0.0600129)

Ziecik A, Tilton JE, Weigl R \& Williams GL 1983 Plasma luteinizing hormone during pregnancy in the pig. Animal Reproduction Science $\mathbf{5}$ 213-218. (https://doi.org/10.1016/0378-4320(83)90029-5)

Ziecik AJ, Stanchev PD \& Tilton JE 1986 Evidence for the presence of luteinizing hormone/human chronic gonadotropin - binding sites in the porcine uterus. Endocrinology 119 1159-1163. (https://doi.org/10.1210/ endo-119-3-1159)

Ziecik AJ, Bodek G, Ciereszko R, Stepien A \& Kotwica G 2001 Involvement of gonadotropins in induction of luteolysis in pigs. Reproductive Biology $133-50$.

Ziecik AJ, Przygrodzka E \& Kaczmarek MM 2017 Corpus luteum regression and early pregnancy maintenance in pigs. In The Life Cycle of the Corpus Luteum, pp 227-248. Ed R Meidan. Switzerland: Springer International Publishing. (https://doi.org/10.1007/978-3-319-43238-0_12)

Zmijewska A, Franczak A \& Kotwica G 2012 Role of interleukin-1 $\beta$ in the regulation of porcine corpora lutea during the late luteal phase of the cycle and during pregnancy. Acta Veterinaria Hungarica 60 395-407. (https://doi.org/10.1556/AVet.2012.034)

Zorrilla LM, Irvin MS \& Gadsby JE 2009 Protein kinase C isoforms in the porcine corpus luteum: temporal and spatial expression patterns. Domestic Animal Endocrinology 36 173-185. (https://doi.org/10.1016/j. domaniend.2008.10.008)

Zorrilla LM, Sriperumbudur R \& Gadsby JE 2010 Endothelin-1, endothelin converting enzyme- 1 and endothelin receptors in the porcine corpus luteum. Domestic Animal Endocrinology 38 75-85. (https://doi. org/10.1016/j.domaniend.2009.08.006)

Zorrilla LM, D'Annibale MA, Swing SE \& Gadsby JE 2013 Expression of genes associated with apoptosis in the porcine corpus luteum during the oestrous cycle. Reproduction in Domestic Animals 48 755-761. (https:// doi.org/10.1111/rda.12156)

Received 30 October 2017

First decision 4 December 2017

Revised manuscript received 27 April 2018

Accepted 22 May 2018 